\title{
THE INFLUENCE OF SERVICE QUALITY AND SALES PROMOTION ON PURCHASE DECISIONS AT ACI MAS JAY'S MEATBALLS BANDUNG CITY
}

\author{
Naya Astina Nur ${ }^{1}$, Ae Suaesih ${ }^{2}$ \\ 1, 2 Program Studi Strata Satu Manajemen Universitas Sangga Buana \\ ${ }^{1}$ korespondensi : kakangkarina@gmail.com
}

\begin{abstract}
Today's increasingly fierce business competition requires companies to be more active in attracting and retaining customers. This requires companies to be more creative in carrying out their business activities. This study aims to identify the effect of service quality and promotion on consumer purchasing decisions for Bakso Aci Mas Jay. This research uses descriptive and confirmatory research methods and quantitative methods. This study used primary data from questionnaires and secondary data obtained from Bakso Aci Mas Jay. The population in this research is the consumers of Bakso Aci Mas Jay. The research sample used accidental sampling, so that a total of 100 illustrations were obtained. The results of the analysis based on the coefficient of determination of service quality and the influence of promotion on purchasing decisions are $52.1 \%$, and the remaining $47.9 \%$ which is influenced by other aspects not listed in this study. Based on the results of the analysis, service quality (X1) does not significantly affect purchasing decisions (Y). The promotion (X2) shows if it has a significant influence on purchasing decisions (Y).
\end{abstract}

Keywords: Service Quality, Sales Promotion, and Purchase Decision

\section{INTRODUCTION}

Companies must prioritize service quality because it affects customer satisfaction. Service quality is an effort to bring comfort to consumers, and make consumers feel they have more value than expected. Service quality is the level of excellence that is expected and controlled in order to meet consumer needs [1]. Consumers usually consider it before making a purchase decision, in this case promotion is an aspect that must be considered by consumers before buying products provided by the company. Promotion is a key element of any marketing activity consisting of a series of incentive tools, most of which are short term, designed to induce consumers or trade to buy a particular product or service more quickly or more quickly [2].

\section{LITERATURE REVIEW}

Consumers expect the quality of service provided in accordance with consumer expectations. In this case, the company will certainly try their best to provide good service or service (quality of service) to consumers. This is the company's efforts to be able to compete with competitors. Service quality is defined as a dynamic condition related to products, services, human resources, processes, and areas that meet or exceed expectations [3]. Five service quality gaps needed for service delivery were identified, namely: knowledge gaps, standards gaps, delivery gaps, communication gaps, and service gaps [4].

\section{METHOD}

The research method used is descriptive and verification research methods. Descriptive 
methods are used to analyze data by describing or describing the information collected, and are not intended to make general or general conclusions. This research uses descriptive research procedures and approaches with quantitative methods. Meanwhile, verification in this research aims to provide answers to these questions, namely to find out how much influence service quality and promotion have on purchasing decisions. This study used primary information from the questionnaire and secondary information obtained from Bakso Aci Mas Jay. The population in this study are consumers of Bakso Aci Mas Jay. The study sample was taken using the accidental sampling method so that the conclusions obtained were samples, Multiple Linear Regression, coefficient of determination, hypothesis testing using t-test and F-test, [5].

\section{RESULTS AND DISCUSSION}

The survey was conducted by the author by distributing questionnaires to consumers of Bakso Aci Mas Jay in Bandung City, who were used as respondents in this study to obtain evidence regarding the Effect of Service Quality and Sales Promotion on Purchase Decisions at Bakso Aci Mas Jay in Bandung.

Table 1: Coefficient of Determination

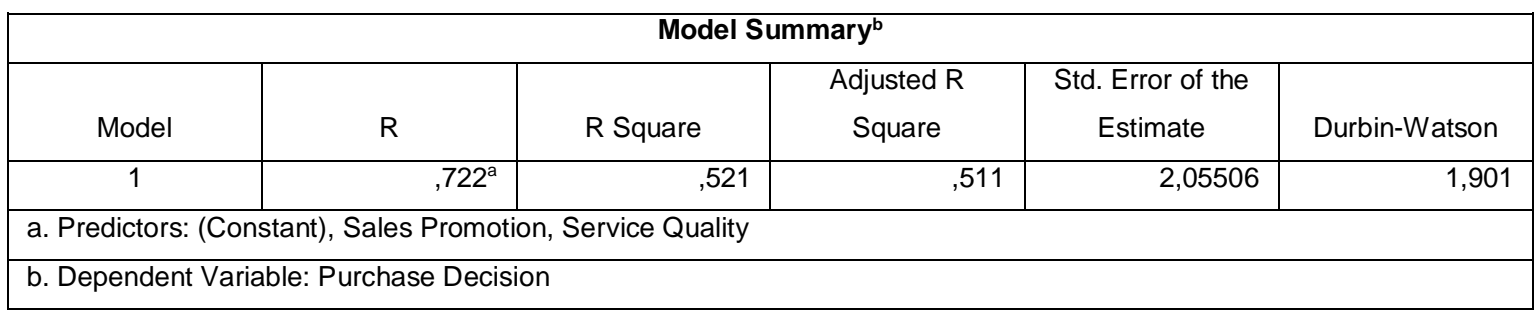

Based on the results in Table 1, the results of data processing show the coefficient value determination of 0.521 . The results of these calculations are the average service quality and the impact of sales promotion activities on purchasing decisions is $52.1 \%$ while the remaining $47.9 \%$ is influenced by other factors not examined in this study.

Table 2: Multiple Regression Analysis Results

\begin{tabular}{|c|c|c|c|c|c|c|}
\hline \multicolumn{7}{|c|}{ Multiple Regression Coefficients ${ }^{a}$} \\
\hline \multirow{2}{*}{\multicolumn{2}{|c|}{ Model }} & \multicolumn{2}{|c|}{$\begin{array}{l}\text { Unstandardized } \\
\text { Coefficients }\end{array}$} & \multirow{2}{*}{$\begin{array}{c}\begin{array}{c}\text { Standardized } \\
\text { Coefficients }\end{array} \\
\text { Beta }\end{array}$} & \multirow[t]{2}{*}{$\mathbf{t}$} & \multirow[t]{2}{*}{ Sig. } \\
\hline & & B & $\begin{array}{l}\text { Std. } \\
\text { Error }\end{array}$ & & & \\
\hline \multirow[t]{3}{*}{1} & (Constant) & 4,569 & 1,390 & & 3,288 & 001 \\
\hline & $\begin{array}{l}\text { Service } \\
\text { Quality }\end{array}$ &,- 098 & 071 &,- 107 & 1,391 & , 167 \\
\hline & $\begin{array}{c}\text { Sales } \\
\text { Promotion }\end{array}$ & ,725 & ,074 & ,759 & 9,843 & ,000 \\
\hline
\end{tabular}


The value of 4.569 means a constant number which means that $\mathrm{X} 1$ (service quality) as the independent variable and X2 (sales promotion) has a constant value so that service quality is worth 4.569.The value of -0.098 means that the regression coefficient number means that each increase in one service quality score will increase the $\mathrm{Y}$ variable (sales promotion) by -0.098 with the assumption that the other independent variables are constants. Because the value isconstant (-), so it can be said that service quality (X1) does not positively affect purchasing decisions ( $\mathrm{Y}$ ).

A value of 0.725 means that the regression coefficient of the X2 variable (sales promotion) is equal to explaining if each increase in one score or sales promotion will increase the $\mathrm{Y}$ variable (purchase decision) by 0.725 . Because the constant value (+), it can be concluded if Sales Promotion (X2) has a negative effect on purchasing decisions (Y)

Table 3: Hypothesis Test

\begin{tabular}{|c|c|c|c|c|}
\hline Variable & t Count & t Table & Sig & Description \\
\hline $\mathrm{X} 1$ & $-1,391$ & 1,66071 &, 167 & Not Significant \\
\hline $\mathrm{X} 2$ & 9,843 & 1,66071 &, 000 & Significant \\
\hline
\end{tabular}

According to the results of the above table, if the t-count value of the $\mathrm{X} 1$ variable is -1 , you can get 391, and the t-count value of the X2 variable is 9.842 . Since $\mathrm{X} 1(-1,391)<\mathrm{t}$ count value of $t$ table $(1,66071)$, it can be said that there is no significant influence between service quality and purchase decision. And t count X2 $(9,843) \mathrm{t}$ table $(1,66071)$ value, so it can be said that promotion and purchasing decisions have a significant impact.

\section{CONCLUSION}

Based on the results of the studies that have been carried out and the review of the impact of service quality and promotion on Bakso Aci Mas Jay's purchasing decisions in Chapter 4, it can be concluded that service quality will not affect and does not significantly affect Bakso Aci Mas Jay's purchases, Decide It can be concluded that the quality of service will not and will not significantly affect Bakso
Aci Mas Jay's purchase decision. From the significance value of 0.05 of 0.167 , it can be seen that the $\mathrm{t}$-count value is located in the $\mathrm{H} 0$ region. As we all know, promotion will significantly affect the purchase decision, its significance value is 0.05 , and it can be seen whether the $\mathrm{t}$ count value is in the rejection area of H0. Based on the result that the correlation coefficient R-squared is 0.521 , it shows that if $64.5 \%$ of the types have strong bonds, otherwise the rest may be affected by other aspects that have not been investigated.

\section{REFERENCES}

[1]. Fandy Tjiptono dan Gregorius Chandra 2016. Service, Quality \& Satisfaction. Yogyakarta.

[2]. Kotler Philip Lane, Kevin Keller 2016. Marketing Managaement. Pearson Education Limited.

[3] Ajan Shrestha 2015. Customer A case Study Of Baskin Robbins Ica - Cream Franchise Thailand. Bangkok University. 
[4] Ari Setiyaningrum, Jusuf Udaya \& Efendi 2015. Prinsip Prinsip Pemasaran. Andi.

[5] Familmaleki 2014. "Analyzing the Influence of Sales Promotion on Customer Purchasing Behavior." International Journal of

[6]. Regita Nurul Ramadhani Taofiq 2019. "Pengaruh Electronic Word Of Mouth Terhadap Keputusan Pembelian." Univeristas Pendidikan
Indonesia, Bandun.

[7]. Solihat, Apriwati 2018. "Pengaruh Promosi Penjualan Dan Kualitas Pelayanan." JOM FISIP 5 No.1.

[9] Sugiyono 2018. Metode Penelitian Kualitatif, Kuantitatif, Dan $R \& D$. Bandung: CV. Alfabeta.

[9], Fandy Tjiptono. 2015. Strategi Pemasaran. Edisi 4. Yogyakarta: Andi. 